\title{
Soil response to acid input in a titration experiment
}

\author{
HELINÄ HARTIKAINEN
}

Hartikainen, H. 1992. Soil response to acid input in a titration experiment. Agric. Sci. Finl. 1: 577-585. (Dept. Applied Chem. Microbiol., SF-00014 University of Helsinki, Finland.)

Cultivated surface soil samples of an acid Gleysol (soil 1, pH 4.9) and a slightly acid Podzol (soil 2, pH 6.7) were equilibrated for $48 \mathrm{~h}$ with 0 to $144 \mathrm{meq} \mathrm{H}^{+} \mathrm{kg}^{-1}$ by a batch technique designed to simulate reactions of acid load with soil constituents. The $\mathrm{pH}$ of the titration suspensions ranged in soil 1 from 5.6 to 3.3 , in soil 2 from 7.2 to 4.7 . The exchange reaction with base cations on variable charge sites was an important mechanism for $\mathrm{H}^{+}$inactivation. The quantities of cation equivalents released were, however, lower than the proton equivalents added. Calcium dominated the supernatant solutions, but as related to exchangeable reserves, $\mathrm{Mg}$ seemed to be more susceptible to acidification at high soil $\mathrm{pH}$. Protons were also consumed in the mobilization of divalent base cations from a non-exchangeable pool to an exchangeable one.

The experimental soils differed in their response of acid cation fractions to proton loading. In the rather neutral soil 2, the quantities of soluble and exchangeable acid cations were very low and not affected by acidification. The Al dissolved by proton attack was immobilized by complexation reactions. This mechanism did not operate in the acid soil 1 where the proton loading markedly increased the exchangeable $\mathrm{Al}$ pool and, consequently, the soluble $\mathrm{Al}$ in the supernatant solution. This was associated with a simultaneous reduction in the complexed $\mathrm{Al}$ and a small increase in complexed $\mathrm{Fe}$. Furthermore, acidification diminished the effective cation exchange capacity (ECEC) decisively less in soil 1 than in soil 2, because the increase in exchangeable Al markedly compensated the reduction in the exchangeable base cations. As compared to freelydrained systems, the batch titration overestimated the release of $\mathrm{Al}$ to solution phase.

Key words: pH-buffering, acidification, cation exchange, complexation

\section{Introduction}

Soil acidification is characterized by intensity and capacity factors. Intensity factors are determined by chemical properties and are independent of the size of the system considered, whereas capacity factors are a function of the size of the system (VAN BREEMEN et al. 1983). Soil $\mathrm{pH}$ is an attribute indicating the intensity of acidity as well as the chemical and biological conditions of a soil. Its alteration in response to acid loading is determined by the buffering properties of the respective soil. The impact of acid precipitation in a special edaphic ecosystem is dependent on the type of buffering reactions in volved. Buffering by certain mechanisms can be ample but ecologically harmful (e.g. ULRICH 1981, SCHWERTMANN et al. 1987).

In Finland, the soil factors responsible for the 
Table 1. Characteristics of the test soils.

\begin{tabular}{|c|c|c|c|c|c|c|c|c|}
\hline Soil & $\begin{array}{c}\text { Clay } \\
\%\end{array}$ & $\begin{array}{l}\text { Silt } \\
\%\end{array}$ & $\begin{array}{c}\mathrm{pH} \\
\left(\mathrm{CaCl}_{2}\right)\end{array}$ & $\underset{\%}{\text { Org. C }}$ & $\begin{array}{l}\mathrm{CEC}_{\text {pot }} \\
\text { meq kg } \mathrm{kg}^{-1}\end{array}$ & $\mathrm{Fe}_{\mathrm{ox}}$ & $\frac{\mathrm{Al}_{\mathrm{ox}}}{\mathrm{mmol} \mathrm{kg}^{-1}}$ & $\mathrm{Mn}_{\mathrm{ox}}$ \\
\hline 1 & 27 & 22 & 4.9 & 4.6 & 268 & 88 & 95 & 1 \\
\hline 2 & 13 & 15 & 6.7 & 3.6 & 168 & 61 & 178 & 1 \\
\hline
\end{tabular}

buffer action have been previously investigated statistically in a study carried out with 84 non-calcareous mineral soils (HARTIKAINEN 1986). The present paper reports the first part of a series of experiments aimed to monitor experimentally the acid-induced changes in soils and soil extracts as well as the role of various soil components in buffering reactions. In this study, the effect of acidification on soil elements and on their mobilization was investigated by a titration procedure. A titration curve for soil combines the two soil acidification characteristics: acid addition refers to the capacity and $\mathrm{pH}$ shows the intensity factor. In addition, it integrates these factors to describe buffering reactions by soil.

\section{Material and methods}

The titration experiment was carried out with two cultivated fine sand soils of very different $\mathrm{pH}$. The samples taken from the surface layers are described in Table 1. Soil 1, a Gleysol from the postglacial sediment, was taken from the Viikki Experimental Farm (University of Helsinki) near the Gulf of Finland, and soil 2, a Podzol from the glacial till, from Northern Karelia. The clay fraction of the soils in both regions are dominated by illite, the other clay minerals being chlorite and vermiculite (CARLSON and HARTIKAINEN, unpublished). Soil samples were analyzed for $\mathrm{pH}$ in a 1:2.5 $0.01 \mathrm{M} \mathrm{CaCl}_{2}$ suspension, organic carbon by a $\mathrm{CHN}$ analyzer and soil texture according to ELONEN (1971). Potential $\mathrm{CEC}$ was determined at $\mathrm{pH} 7.0$ by using $\mathrm{NH}_{4} \mathrm{OAc}$ solution (four extractions). Adsorbed $\mathrm{NH}_{4}{ }^{+}$replaced by $\mathrm{KCl}$ was determined by distillation. Semiamorphous $\mathrm{Al}_{\text {ox }}, \mathrm{Fe}_{\text {ox }}$ and $\mathrm{Mn}_{\text {ox }}$ were extracted according to a modified Tamm's method (NISKA NEN 1989) with $0.05 \mathrm{M} \mathrm{NH}_{4}$-oxalate (pH 3.3) at a soil to solution ratio of 1:20 and determined by atomic absorption spectrophotometry (AAS).

A set of $5 \mathrm{~g}$ soil samples (three replicates) was weighed into centrifuge tubes and $50 \mathrm{ml}$ of water or a $\mathrm{H}_{2} \mathrm{SO}_{4}$ solution of a concentration of 0.0012 , $0.0024,0.0036,0.0048,0.0060$ or $0.0072 \mathrm{M}$ was added. The suspensions were shaken for one min and allowed to stand for $48 \mathrm{~h}$. The $\mathrm{pH}$ of the suspensions was measured after manual reshaking. The supernatant solution obtained after centrifugation was filtered through a hard filter paper (Schleicher \& Schuell $589^{3}$ ) and analyzed for $\mathrm{Ca}, \mathrm{Mg}, \mathrm{Fe}$ and $\mathrm{Mn}$ by AAS, for K and Na by flame photometry and for Al by the Aluminon method (YUAN and FISKELL 1959). The soil samples treated with water or acid were washed with $30 \mathrm{ml}$ of ethanol and analyzed for exchangeable cations extracted with four $25 \mathrm{ml}$ portions of $1 \mathrm{M} \mathrm{NH} 4 \mathrm{Cl}$. Another set of soil samples was treated similarly with water and acid. After washing with ethanol the soil samples were analyzed for exchangeable and complexed cations according to a modified JUO and KAMPRATH's method (1979) by extracting with four $25 \mathrm{ml}$ portions of $0.33 \mathrm{M} \mathrm{CuCl}_{2}$. Similarly to the study of NÄTSCHER (1987), the $\mathrm{CuCl}_{2}$ solution was adjusted to the same ionic strength as the $\mathrm{NH}_{4} \mathrm{Cl}$ solution. The soil cations were determined as described above, except for $\mathrm{Al}$ which was determined by AAS. 


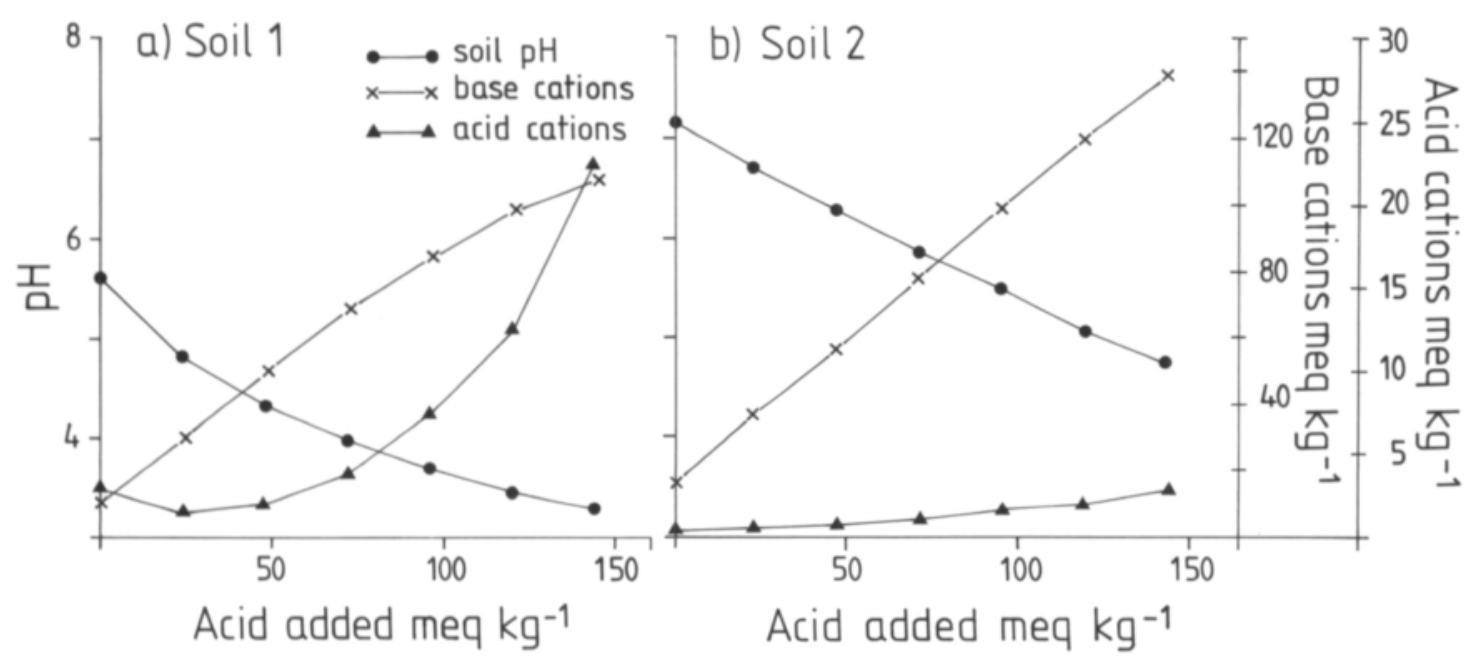

Fig. la-b. Suspension $\mathrm{pH}$ and the release of the base and acid cations from the soil to solution in the titration experiment.

\section{Results}

\section{Titration solutions}

The effect of increasing acid load on the $\mathrm{pH}$ of the soil suspensions and on the release of cations from soil to solution is described in Figure 1a-b. The cation species non-hydrolyzable at $\mathrm{pH}$ values prevailing in soils $(\mathrm{Ca}, \mathrm{Mg}, \mathrm{K}, \mathrm{Na})$ are referred to as basic cations, the hydrolyzable species ( $\mathrm{Al}, \mathrm{Fe}, \mathrm{Mn}$ ) as acid cations. When calculating the equivalents of the acid species, Fe and $\mathrm{Mn}$ were assumed to appear as divalent ions and $\mathrm{Al}$ as a trivalent one.

The reciprocal of the slope of the titration graph stands for the buffer capacity (BC), defined as the number of mmols or meq of $\mathrm{H}^{+}$that must be added to $1 \mathrm{~kg}$ of soil to lower $\mathrm{pH}$ by one unit. When using $\mathrm{pH}$ of the zero point of titration (i.e. $\mathrm{pH}$ in $\mathrm{H}_{2} \mathrm{O}$ ) as a reference $\mathrm{pH}$, the buffer capacity was higher for soil 2 (55 meq) than for soil 1 (33 meq). The experimental soils differed also in the shape of the titration curves. At high pH's obtained for soil 2 (range 7.2-4.7) the graph was linear implying the $\mathrm{BC}$ to be rather independent of $\mathrm{pH}$. In soil 1 , on the contrary, the $\mathrm{pH}$ was lower (range 5.6 - 3.3) and $\mathrm{BC}$ increased with decreasing $\mathrm{pH}$. However, $\mathrm{pH}$ being a logarithmic measure the $\mathrm{BC}$ values of various soils are comparable only at the same $\mathrm{pH}$ level. The comparison of the graphs at a coincident $\mathrm{pH}$ range (5.6-4.7) revealed the slope to be steeper for soil 1 than for soil 2. This suggests that, at this $\mathrm{pH}$ range, soil 2 was more effectively buffered against acid.

In both soils, the basic cations dominated the titration solutions, $\mathrm{Ca}$ being the main cation, followed by $\mathrm{Mg}$ and $\mathrm{K}$. The difference between the cation quantities dissolved in the acid and water treatments was taken to describe the acid-induced release into supernatant. Similarly, the differences calculated for each acid increment of $24 \mathrm{meq} \mathrm{kg}{ }^{-1}$ were considered to measure the gradual dissolution as response to progressing acidification. The results in Table 2 (only the statistically significant differences are recorded) reveal that with increasing acid load the differential release of $\mathrm{Mg}$ decreased proportionately most. The release of $\mathrm{Ca}$ dimished clearly in soil 1 but remained rather constant in soil 2. Na was not affected.

The portion of acid cations in the solutions, mainly $\mathrm{Al}$, distinctly increased with progressing acidification in soil 1 , but very slightly in soil 2 where the release of $\mathrm{Al}$ was of the same magnitude as that of $\mathrm{Mn}$ (on the equivalent basis). No Fe was dissolved. 
Table 2. Differential dissolution of cations (meq $\mathrm{kg}^{-1}$ ) calculated for each acid increment of $24 \mathrm{meq} \mathrm{kg}^{-1}$

\begin{tabular}{|c|c|c|c|c|c|c|c|c|}
\hline $\begin{array}{l}\text { Increment } \\
\text { of acid } \\
\text { meq kg-1 }\end{array}$ & $\mathrm{Ca}$ & $\mathrm{Mg}$ & $\mathrm{K}$ & $\mathrm{Na}$ & $\mathrm{Al}$ & $\mathrm{Fe}$ & $\mathrm{Mn}$ & $\Sigma$ \\
\hline & & & & Soil 1 & & & & \\
\hline $0 \rightarrow 24$ & 16.7 & 2.1 & 0.7 & - & -0.3 & -1.2 & 0.2 & 18.2 \\
\hline $24 \rightarrow 48$ & 18.4 & 2.1 & 0.7 & - & 0.5 & 0.2 & 0.1 & 22.0 \\
\hline $48 \rightarrow 72$ & 16.0 & 1.7 & 0.5 & - & 1.5 & -0.1 & 0.2 & 19.8 \\
\hline $72 \rightarrow 96$ & 14.2 & 1.3 & 0.5 & - & 3.6 & 0.2 & 0.1 & 19.9 \\
\hline $96 \rightarrow 120$ & 11.2 & 1.1 & 0.4 & 0.2 & 5.2 & 0.1 & 0.1 & 18.3 \\
\hline \multirow[t]{2}{*}{$120 \rightarrow 144$} & 7.9 & 0.9 & 0.3 & 0.1 & 9.1 & 0.4 & 0.2 & 18.9 \\
\hline & & & & Soil 2 & & & & \\
\hline $0 \rightarrow 24$ & 15.0 & 3.9 & 0.7 & - & - & -0.1 & 0.2 & 19.7 \\
\hline $24 \rightarrow 48$ & 16.3 & 3.0 & 0.5 & 0.2 & - & - & 0.3 & 20.3 \\
\hline $48 \rightarrow 72$ & 20.2 & 2.7 & 0.6 & 0.4 & 0.1 & - & 0.3 & 24.3 \\
\hline $72 \rightarrow 96$ & 18.4 & 2.0 & 0.4 & -0.1 & 0.3 & - & 0.3 & 21.3 \\
\hline $96 \rightarrow 120$ & 18.4 & 2.0 & 0.2 & 0.1 & 0.3 & - & 0.2 & 21.2 \\
\hline $120 \rightarrow 144$ & 18.2 & 0.7 & 0.4 & 0.2 & 0.5 & - & 0.5 & 20.5 \\
\hline
\end{tabular}

Table 3. Cations (meq kg-1) replaced by $\mathrm{NH}_{4} \mathrm{Cl}$ in soil samples after titration treatment.

\begin{tabular}{|c|c|c|c|c|c|c|c|c|}
\hline $\begin{array}{l}\text { Acid } \\
\text { added } \\
\text { meq kg }{ }^{-1}\end{array}$ & $\mathrm{Ca}$ & $\mathrm{Mg}$ & K & $\mathrm{Na}$ & $\mathrm{Al}$ & $\mathrm{Fe}$ & $\mathrm{Mn}$ & $\Sigma$ \\
\hline \multicolumn{9}{|c|}{ Soil 1} \\
\hline 0 & 101.8 & 11.7 & 7.4 & 2.3 & 4.1 & 2.2 & 1.1 & 130.6 \\
\hline 24 & 88.5 & 9.5 & 6.4 & 2.5 & 9.2 & 1.7 & 0.9 & 118.7 \\
\hline 48 & 75.4 & 7.6 & 5.8 & 2.1 & 20.6 & 0.9 & 0.8 & 113.2 \\
\hline 72 & 64.3 & 6.5 & 5.4 & 2.3 & 31.1 & 0.9 & 0.7 & 111.2 \\
\hline 96 & 53.6 & 5.2 & 5.0 & 2.2 & 40.8 & 0.8 & 0.6 & 108.2 \\
\hline 120 & 45.6 & 4.6 & 4.8 & 2.3 & 51.4 & 0.9 & 0.5 & 110.1 \\
\hline 144 & 41.5 & 4.0 & 4.6 & 2.3 & 58.5 & 0.9 & 0.5 & 112.3 \\
\hline \multicolumn{9}{|c|}{ Soil 2} \\
\hline 0 & 124.0 & 16.6 & 5.0 & 2.3 & 0.0 & 0.1 & 1.2 & 149.2 \\
\hline 24 & 117.9 & 14.2 & 4.4 & 2.2 & 0.0 & 0.1 & 1.6 & 140.4 \\
\hline 48 & 108.3 & 11.5 & 3.9 & 1.9 & 0.1 & 0.1 & 2.0 & 127.8 \\
\hline 72 & 104.0 & 9.8 & 3.7 & 2.3 & 0.2 & 0.1 & 2.0 & 122.1 \\
\hline 96 & 95.0 & 7.9 & 3.5 & 2.2 & 0.3 & 0.2 & 2.3 & 111.4 \\
\hline 120 & 86.9 & 6.8 & 3.1 & 2.1 & 0.7 & 0.1 & 2.1 & 101.8 \\
\hline 144 & 74.1 & 5.7 & 2.9 & 2.2 & 1.4 & 0.2 & 2.1 & 88.6 \\
\hline
\end{tabular}

\section{Soil samples}

Acidification markedly depleted the reserves of the basic exchangeable cations (Table 3). Magnesium was reduced proportionately more than $\mathrm{Ca}$ and $\mathrm{K}$, but no changes were found for $\mathrm{Na}$. The total quantity of $\mathrm{NH}_{4} \mathrm{Cl}$-replaceable cations, taken to represent effective cation exchange capacity (ECEC), diminished decisively more in soil 2 than in soil 1 . This was attributable to the fact that in soil 1 the decrease in the exchangeable basic cations was to a marked degree compensated by an increase in the exchangeable Al. The exchangeable Fe and Mn, on the other hand, were lower in the acidified subsamples than 
Table 4 . The sums (meq $\mathrm{kg}^{-1}$ ) of base cations dissolved in the supernatant solution and left in the exchangeable form in soil after titration.

\begin{tabular}{ccccccc}
\hline & $\begin{array}{c}\text { Acid } \\
\text { added } \\
\text { meq kg }\end{array}$ & Ca & Mg & $\mathrm{K}$ & $\mathrm{Na}$ & $\Sigma$ \\
\hline Soil 1 & 0 & 105.8 & 13.6 & 9.4 & 5.1 & 133.9 \\
& 72 & 119.5 & 14.2 & 9.2 & 5.0 & 147.9 \\
Soil 2 & 144 & 130.4 & 15.1 & 9.6 & 5.2 & 160.3 \\
& 0 & 132.0 & 19.2 & 7.9 & 4.7 & 163.8 \\
& 72 & 163.5 & 21.9 & 8.4 & 5.4 & 199.0 \\
& 144 & 188.6 & 22.5 & 8.5 & 5.3 & 224.9 \\
\hline
\end{tabular}

Table 5. Cations in complexed form $\left(\mathrm{meq}^{-1}\right)$ in the soil samples after titration.

\begin{tabular}{rrrrrr}
\hline $\begin{array}{l}\text { Acid } \\
\text { added } \\
\text { meq kg }\end{array}$ & Ca & Mg & Al & Fe & Mn \\
\hline \multicolumn{7}{c}{ Soil 1 } \\
0 & 10.2 & 0.8 & 84.1 & -0.7 & 0.1 \\
24 & 9.1 & 1.4 & 84.2 & 0.2 & 0.1 \\
48 & 5.1 & 0.7 & 82.4 & 1.6 & 0.1 \\
72 & 4.3 & 0.3 & 80.9 & 2.1 & 0.1 \\
96 & 3.3 & 0.5 & 77.8 & 2.4 & 0.1 \\
120 & 1.0 & 0.5 & 70.9 & 2.9 & 0.1 \\
144 & -0.3 & 0.3 & 66.1 & 3.3 & 0.1 \\
& \multicolumn{7}{c}{ Soil 2 } & & \\
0 & 32.4 & 1.0 & 37.7 & 0.0 & 4.4 \\
24 & 31.4 & 1.0 & 39.8 & 0.0 & 4.2 \\
48 & 30.0 & 0.9 & 45.1 & 0.0 & 3.8 \\
72 & 21.2 & 0.7 & 52.3 & 0.1 & 3.7 \\
96 & 22.5 & 1.3 & 51.6 & 0.0 & 3.4 \\
120 & 13.7 & 0.7 & 57.3 & 0.1 & 3.5 \\
144 & 12.4 & 0.8 & 66.7 & 0.1 & 3.5 \\
\hline
\end{tabular}

in the water-treated ones. In soil 2, the exchangeable $\mathrm{Al}$ was found in very small quantities and only at the highest acid doses. In this soil, the highest acid addition almost doubled the exchangeable $\mathrm{Mn}$ but had no effect on Fe.

For quantitative estimation of the acid-derived changes in the basic cations, the cation equivalents dissolved in the supernatant solutions were summed up to the residual exchangeable reserves (compiled data given in Table 4). The lower sums for the water-treated subsamples as compared to those for the acid-loaded ones indicate that proton additions evoked mobilization from a non-exchangeable pool to the exchangeable and/or soluble fraction. For Ca, and to a lesser extent for $\mathrm{Mg}$, release from these reserves was enhanced with progressing acidification. For the monovalent species, the phenomenon was less pronounced. Furthermore, the cation supply from non-exchangeable reserves appeared to be of greater significance in soil 2 .

The differences between the $\mathrm{CuCl}_{2}$ - and $\mathrm{NH}_{4} \mathrm{Cl}$ extractable cations were considered to represent non-exchangeable reactive reserves, mainly organically bound ones. Acidification gradually exhausted $\mathrm{Ca}$ in this fraction in soil 1 and markedly decreased it in soil 2. Complexation of $\mathrm{Mg}$ was immaterial and very slightly influenced by acid additions. For acidic cations, $\mathrm{Al}$ dominated the complexed reserves. In soil 1, acidification reduced this $\mathrm{Al}$ pool but increased the corresponding Fe pool. In soil 2 , on the contrary, increasing proton load resulted in an accumulation of $\mathrm{Al}$ in a complexed form and a slight decrease in complexed Mn.

\section{Discussion}

In order to monitor acid-evoked changes in the soil and solution cations, the titration was performed without background electrolyte. This technique, previously used e.g. by WELLS and DAVEY (1966) and FEDERER and HORNBECK (1985), obviously underestimates the buffer capacity (BC). The present experiment produced lower values than obtained in 
a parallel percolation experiment with the same soils (HARTIKAINEN 1992a) where soil $\mathrm{pH}$ was measured in a $\mathrm{CaCl}_{2}$ suspension after elution. Obviously, in the titration experiment without background electrolyte the matrix solution affected dissimilarly soil $\mathrm{pH}$ in the various treatments, the $\mathrm{pH}$ being erroneously high in the water and maybe in the most dilute acid solution suspensions. This hypothesis is supported by the finding that the difference between the titration and percolation experiment was more pronounced for soil 1 in which the portion of salt replaceable acid cations was high. Also the higher $\mathrm{BC}$ for soil 2 of higher $\mathrm{pH}$ is in contradiction with general response of non-calcareous soils, confirmed e.g. in the earlier titration study at a constant ionic strength (HARTIKAINEN 1986), that the acid buffering is lowest in soils with the highest $\mathrm{pH}$. This behaviour is attributable to the logarithmic nature of $\mathrm{pH}$.

The marked reduction in the exchangeable base cations in the acid-treated soils evidences inactivation of $\mathrm{H}^{+}$by cation exchange. Furthermore, the decrease in ECEC indicates the buffering to have taken place by protonation of variable charge sites. The reduction in ECEC was mainly attributable to the depletion in the divalent base cations. The buffering by exchange reactions can be concluded to be mainly attributable to humic material. It is known that added $\mathrm{H}^{+}$ions will associate first with the conjugate base of the weakest acid in the soil. Owing to the weak-acid nature, organic matter with variable charge has a preference as a proton acceptor.

The buffering by the exchange on the permanent charges can be concluded to be rather ineffective because these sites act like strongly acidic anions so that $\mathrm{H}^{+}$ions linked to them are strongly ionized. The $\mathrm{H}^{+}$ion has to compete with other cations present in ambient solution for the permanently charged exchange sites. Its preference for mineral sites has been found to be between $\mathrm{K}$ and $\mathrm{Na}$ (GILBERT and Laudelout 1965, Talibudeen 1981). Actually, $\mathrm{H}^{+}$ions are weakly adsorbed on the permanent charge sites and will remain in a salt-replaceable form and, thus, are not really buffered. Therefore, base cations on the permanently charged sites are hardly exchanged directly by $\mathrm{H}^{+}$ions but by lattice cations (mainly Al) (VEITH and SCHWERTMANN 1972) or oxide cations (HARTIKAINEN 1986) released by proton attack.

Extraction with $\mathrm{NH}_{4} \mathrm{Cl}$ is known to replace $\mathrm{Al}$ only from the permanent charge surfaces. Thus, the significant increase in $\mathrm{NH}_{4} \mathrm{Cl}$-replaceable $\mathrm{Al}$ upon progressing acidification in soil 1 evidences that, in this soil, exchange occurred markedly also on the mineral surfaces. It is noteworthy that with increasing $\mathrm{Al}$ saturation the exchangeable divalent base cations were highly reduced, whereas the monovalent species were only slightly affected. This suggests that, on permanent charges, exchangeable $\mathrm{Al}$ replaced mainly divalent species dominating the cation composition. The increase in the $\mathrm{Al}$ saturation was reflected as a marked increase in solution $\mathrm{Al}^{3+}$. In the parallel percolation experiment (HARTIKAINEN 1992b) the increased Al saturation enhanced the Al leaching immaterially. This difference in the reaction patterns is due to a higher increase in the ionic strength (due to $\mathrm{H}_{2} \mathrm{SO}_{4}$ ) in the titration solutions, which is shown to enhance the displacement of $\mathrm{Al}^{3+}$ from exchange sites (REUSS 1983, BRUCE et al. 1989). This reveals that the results obtained for cation exchange in a batch titration are not applicable to freely-drained systems.

The titration results imply that in addition to exchange reactions also other buffering mechanisms were involved. Firstly, the quantities of cations released by acid were lower than the proton equivalents added. Secondly, the depletion in the exchangeable basic cations was smaller than a respective mobilization to solution. The contribution by other buffering reactions in mineral soils of Finland can be concluded also from the titration data published by MÄNTYLAHTI and NISKANEN (1986) showing the $\mathrm{H}^{+}$consumption to be greater than the corresponding reduction in CEC.

In fact, it can be calculated from the data in Table 4 that the highest acid load dissolved 24.6 and 56.6 
meq $\mathrm{kg}^{-1}$ non-exchangeable Ca from soil 1 and 2, respectively. A concomitant increase in $\mathrm{P}$ mobilization $\left(6.7 \mathrm{mg} \mathrm{kg}^{-1}\right.$ in soil 1 and $39.0 \mathrm{mg} \mathrm{kg}^{-1}$ in soil 2) observed in a parallel titration study (HARTIKAINEN 1992, unpublished data) gives reason to suppose that acid dissolved some $\mathrm{Ca}$ from primary or secondary Ca-phosphates, especially in soil 2 .

Magnesium and monovalent cations were released mainly from exchangeable reserves. As found also in earlier studies (JEFFREY and WEBER 1982, HAUN et al. 1988), Na did not respond to acidification. When related to the exchangeable pool, the mobilization of $\mathrm{Mg}$ in soil 2 was proportinately more pronounced than that of $\mathrm{Ca}$. The result suggests that in a soil of high $\mathrm{pH} \mathrm{Mg}$ may be more susceptible to proton load, and in the first phase of acidification it will be lost proportionately more effectively than $\mathrm{Ca}$. The acid-induced impoverishment of $\mathrm{Mg}$ has been reported in numerous studies on forest soils (e.g. ABRAHAMSEN 1980, JEFFREY and WEBER 1982, BOSCH et al. 1983, ZECH and POPP 1983) and also on acid sulphate soils (HARTIKAINEN and YLI-HALLA 1986).

The difference between $\mathrm{CuCl}_{2}$ - and $\mathrm{NH}_{4} \mathrm{Cl}$-extractable cations was assumed to represent nonexchangeable reactive reserves, mainly organically bound ones. $\mathrm{Cu}^{2+}$ has a high affinity for functional groups of humic compounds and is able to replace complexed cations (BLOOM et al. 1979). Being acidic, the $\mathrm{CuCl}_{2}$ solution may extract also some inorganic polymerized metals, but according to OATES and KAMPRATH (1983), it hardly markedly enhances the replacement of $\mathrm{Al}$ from the mineral fraction. Furthermore, because $\mathrm{CuCl}_{2}$ determines the $\mathrm{pH}$ of the extraction mixture (OATES and KAMPRATH 1983), it can be concluded that in the present study the same $\mathrm{Al}$ pool was affected in all treatments.

The role of organic matter in regulating the acidderived changes in soil cations was dependent on the soil $\mathrm{pH}$. In both soils, the acid loading resulted in replacement of the complexed $\mathrm{Ca}$ by $\mathrm{Al}^{3+}$ or $\mathrm{H}^{+}$. The reduction in the complexed $\mathrm{Ca}$ explained a small part of the total mobilization from non- exchangeable reserves. In the slightly acid soil 2 ( $\mathrm{pH}$ 6.7), acidification enhanced the accumulation of $\mathrm{Al}$ into the non-exchangeable complexed fraction. At the same time some dissolution of weaker Mn complexes appeared to take place.

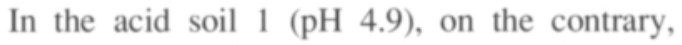
complexed $\mathrm{Al}$ began to decrease and exchangeable $\mathrm{Al}$ to increase from the second acid increment on (suspension $\mathrm{pH}$ 4.3). This response, demonstrating a gradual shift from a non-labile complexed pool to a labile one, was similar to that found by JAMES and RIHA (1984) in soil extracts. The reduction in the complexed reserves was, however, lower than the concomitant increase in the exchangeable and dissolved fractions, which indicates that $\mathrm{Al}$ was mobilized also from mineral components of soil. The decrease in complexed $\mathrm{Al}$ coincided with an accumulation of $\mathrm{Fe}$ in the complexed form, which gives reason to suppose that $\mathrm{Fe}$ dissolved by acid began to replace $\mathrm{Al}$ from the complexation sites. This hypothesis is supported e.g. by the results of SCHNITZER and SKINNER (1965) showing that organic matter has a higher affinity for $\mathrm{Fe}$ than for $\mathrm{Al}$, even though the retention of both metals decreases when $\mathrm{pH}$ is lowered. The replacement of $\mathrm{Al}$ by $\mathrm{Fe}$ did not, however, quantitatively explain the depletion in the complexed $\mathrm{Al}$. This indicates that with increasing acid load, also $\mathrm{H}^{+}$began to compete more effectively with $\mathrm{Al}^{3+}$ for ligand binding sites. Also BLOOM et al. (1979) concluded the $\mathrm{Al}$ replacement by $\mathrm{H}^{+}$on organic matter exchange sites to be an important source of $\mathrm{pH}$ buffering.

The experimental soils differed in their buffering mechanisms, as concluded from the dissimilar shapes of their titration graphs. The results demonstrate that the role of humic material as $\mathrm{H}^{+}$buffering agent is limited at low pH's. Also the complexation of detrimental metals alleviates the effects of proton loading more effectively in soils of high $\mathrm{pH}$, because the stability of the metal complexes decreases with lowering $\mathrm{pH}$. A common feature was that the release of soil elements to supernatant due to acidification did not quantitatively explain the changes in soil chemistry. More detailed studies are 
needed, e.g. to qualify and quantify the role of organic matter in buffering.
Acknowledgements. The author wishes to thank Ms. Marjatta Koivisto, B. Sc., for her skillful technical assistance. This study was financially supported by the Finnish Academy, which is gratefully acknowledged.

\section{References}

Abrahamsen, G. 1980. Acid precipitation, plant nutrients and forest growth. Proc. int. conf. ecol. impact acid precip., Norway 1980: 58-63.

Bloom, P. R., McBride, M. B. \& Weaver, R. M. 1979. Aluminum organic matter in acid soils: Buffering and solution aluminum activity. Soil Sci. Soc. Am. J. 43: 488-493.

Bosch, C., Pfannkuch, E., Baum, U. \& Rehfuess, K. E. 1983. Über die Erkrankung der Fichte (Picea abies Karst.) in der Hochlagen des Bayerischen Waldes. Forstwissensch. Centralblatt 102: 167-181.

Bruce, R. C., Bell, L. C., Edwards, D.G. \& Warrell, L. A. 1989. Chemical attributes of some Queensland acid soils. II Relationship between soil and soil solution phase composition. Aust. J. Soil Res. 27: 353-364.

Elonen, P. 1971. Particle-size analysis of soil. Acta Agr. Fenn. 122: 1-122.

Federer, C. A. \& Hornbeck, J. W. 1985. The buffer capacity of forest soils in New England. Water, Air, and Soil Pollution 26: 163-173.

Gilbert, M. \& Laudelout, H. 1965. Exchange properties of hydrogen ions in clays. Soil Sci. 100: 157-162.

Hartikainen, H. 1986. Acid- and base titration behaviour of Finnish mineral soils. Z. Pflanzenernähr. Bodenk. 149: 522-532.

- 1992a. Soil buffering against acid in a percolation experiment. Manuscript. (Available at the Department of Applied Chemistry and Microbiology, University of Helsinki.)

- 1992b. Responsiveness of various cation species to soil acidification. Manuscript. (Available at the Department of Applied Chemistry and Microbiology, University of Helsinki.)

— \& Yli-halla, M. 1986. Oxidation-induced leaching of sulphate and cations from acid sulphate soils. Water, Air, and Soil Pollution 27: 1-13.

Haun, G. W., Wolt, J. \& Reynolds, J. H. 1988. Effects of simulated acid rain on soil solution composition and orchardgrass seedling viability. Soil Sci. Soc. Am. J. 52: 1037-1043.

JAMES, B. R. \& RiHA, S. J. 1984. Soluble aluminum in acidified organic horizons of forest soils. Can. J. Soil Sci. 64: 637-646.

Jefrerey, J. L. \& WeBER, D. E. 1982. Effects of sulfuric acid rain on major cation and sulfate concentrations of water percolating through two model hardwood forests. J. Environm. Qual. 11: 57-64.

Juo, A. S. R. \& Kamprath, E. J. 1979. Copper chloride as an extractant for estimating the potentially reactive aluminium pool in acid soils. Soil Sci. Soc. Amer. J. 43: 35-38.

Mäntylahti, V. \& Niskanen, R. 1986. Effect of acidification on cation exchange capacity of eight Finnish mineral soils. Acta Agric. Scand. 36: 339-346.

NisKANEN, R. 1989. Extractable aluminium, iron and manganese in mineral soils II Extractability by oxalate and pyrophosphate. J. Agric. Sci. Finl. 61: 79-87.

NÄTSCHER, L. 1987. Art, Menge und Wirkungsweise von Puffersubstanzen in Auflagehorizonten forstlich genutzter Böden des Fichtelgebirges. Dissertation. Technische Universität München-Weihenstephan.

OAtes, K. M. \& Kamprath, E. J. 1983. Soil acidity and liming: I Effect of the extracting solution cation and $\mathrm{pH}$ on the removal of aluminum from acid soils. Soil Sci. Soc. Am. J. 47: 686-689.

Reuss, J. O. 1983. Implications of the calcium-aluminium exchange system for the effect of acid precipitation on soils. J. Environm. Qual. 12: 591-595.

SChNitZer, M. \& SkInNER, S. I. M. 1965. Organo-metallic interactions in soils: 4 . Carboxyl and hydroxyl groups in organic matter and metal retention. Soil Sci. 99: 278-284.

Schwertmann, U., Sússer, P. \& Nätscher, L. 1987. Protonenpuffersubstanzen in Böden. Z. Pflanzenernähr. Bodenk. 150: 174-178.

TAlibudeEn, O. 1981. Cation exchange in soils. In: Greenland, D. J. \& Hayes, M. H. B. (eds.). The chemistry of soil processes. John Wiley \& Sons Chichester. p. 115117.

ULRICH, B. 1981. Ökologische Gruppierung von Böden nach ihrem chemischen Bodenzustand. Z. Pflanzenernähr. Bodenk. 144: 289-305.

V AN BREEMEN, N. 1983. Acidification and alkalinization of soils. Plant and Soil 75: 283-308.

Verth, J. \& Schwertmann, U. 1972. Reaktionen von CaMontmorillonit und Ca-Vermiculit mit Kohlensäure. Z. Pflanzenernähr. Bodenkunde 131: 21-37.

Welis.C. G. \& Davey,C. B. 1966. Cation-exchange characteristics of forest floor materials. Soil Sci. Soc. Amer. Proc. 30: 399-402.

YuAN, T. L. \& Fiskel.. J. G. A. 1959. Aluminium determination. Aluminium studies. Soil and plant analysis of alu- 
minium by modification of the Aluminon method. J. Agr. Food Chem. 7: 115-117.

ZeCH, W. \& Popp, E. 1983. Magnesiummangel, einer der Gründe für das Fichten- und Tannensterben in NO-Bayern. Forstwissensch. Centralblatt 102: 50-55.
Manuscript received September 1992

Helinä Hartikainen

Department of Applied Chemistry and Microbiology

SF-00014 University of Helsinki, Finland

\title{
SELOSTUS
}

\section{Maa-aineksen reaktiot happotitrauksessa}

\author{
HELINÄ HARTIKAINEN
}

Helsingin yliopisto

\begin{abstract}
Laboratoriossa tehdyssä titrauskokeessa seurattiin kasvavien happolisäysten aiheuttamia muutoksia maa-aineksessa ja sitä ympäröivässä liuoksessa. Kokeessa käytettiin kahta viljelymaan muokkauskerroksesta otettua hietanäytettä, joista toinen (maa 1) oli selvästi hapan $\left(\mathrm{CaCl}_{2}-\mathrm{pH} 4,9\right)$ ja toinen (maa 2) vain heikosti hapan ( $\mathrm{pH} 6,7)$. Ilmakuivaa maata (5 g) punnittiin sentrifugiputkiin, joihin lisättiin $50 \mathrm{ml}$ vettä tai rikkihappoliuosta $(0,0012-0,0072 \mathrm{M})$. Suspensioiden $\mathrm{pH}$ mitattiin 48 tunnin kuluttua, minkä jälkeen maa-aines ja liuosfaasi erotettiin sentrifugoimalla ja analysoitiin erikseen.

Vety-ionien sitoutuminen $\mathrm{pH}$ :sta riippuville varauspaikoille (pääasiassa humukseen) emäskationeja syrjäyttämällä oli tärkeä puskurointimekanismi, minkä seurauksena efektiivinen kationinvaihtokapasiteetti (EKVK) pieneni. EKVK:n lasku jäi kuitenkin pienemmäksi alunperin happamassa maanảytteessä 1 , jossa vaihtoreaktioita tapahtui merkittävässä määrin myös mineraaliaineksen pysyvän negatiivisen varauksen omaavilla vaihtopaikoilla. Niihin sitoutuneita vaihtuvia emäskationeja korvautui alumiinilla, jota vapautui maasta vaihtuvaan muotoon happamoitumisen seurauksena. Titraus-
\end{abstract}

liuokseen liukeni eniten kalsiumia, mutta vaihtuviin varoihin suhteutettuna magnesiumia näytti vapautuvan maasta herkemmin etenkin pH:n ollessa korkea. Happamoituminen edisti myös vaihtumattomana olevien emäskationien (lähinnä 2arvoisten) mobilisoitumista vaihtuvaan muotoon. Happamien kationien osalta maanäytteet poikkesivat selvästi toisistaan. Maanäytteessä 2, joka oli alunperin melko neutraali, happamoitumisen seurauksena liuennut alumiini näytti sitoutuvan orgaanisiksi komplekseiksi ja sitä vapautui suurillakin happokuormilla liuokseen erittäin vähän. Sen sijaan maanäytteessä 1 liukoisen alumiinin määrä kasvoi happamoitumisen myötä samanaikaisesti kun vaihtuvan alumiinin määrä maassa lisääntyi merkittävästi ja kompleksoituneen alumiinin määrä pyrki laskemaan. Eri kationien vapautuminen liuosfaasiin ei kuitenkaan kvantitatiivisesti selittänyt maan kemiassa havaittuja muutoksia. Kun titrauskokeen tuloksia verrattiin huuhtomiskokeessa vastaavilla happokäsittelyillä saatuihin tuloksiin, havaittiin mm., että erätitraus yliarvioi alumiinin vapautumista liousfaasiin. 